Portland State University

PDXScholar

Environmental Science and Management

Faculty Publications and Presentations

\title{
Riparian Vegetation Assemblages and Associated Landscape Factors Across an Urbanizing Metropolitan Area
}

\author{
Christa Von Behren \\ Portland State University \\ Andrew Evans Dietrich \\ US Geological Survey \\ J. Alan Yeakley \\ Portland State University, yeakley@pdx.edu
}

Follow this and additional works at: https://pdxscholar.library.pdx.edu/esm_fac

Part of the Plant Sciences Commons, Sustainability Commons, and the Water Resource Management Commons

Let us know how access to this document benefits you.

\section{Citation Details}

von BEHREN, C., DIETRICH, A., \& YEAKLEY, J. (2013). Riparian vegetation assemblages and associated landscape factors across an urbanizing metropolitan area. Ecoscience, 20(4), 373-382.

This Article is brought to you for free and open access. It has been accepted for inclusion in Environmental Science and Management Faculty Publications and Presentations by an authorized administrator of PDXScholar. Please contact us if we can make this document more accessible: pdxscholar@pdx.edu. 


\title{
Riparian vegetation assemblages and associated landscape factors across an urbanizing metropolitan area ${ }^{1}$
}

Christa VON BEHREN ${ }^{2}$, Department of Environmental Science and Management, Portland State University, PO Box 751, Portland, Oregon 97207, USA, e-mail: christav@pdx.edu

Andrew DIETRICH, Department of Environmental Science and Management, Portland State University, PO Box 751, Portland, Oregon 97207, USA, and US Geological Survey, Patuxent Wildlife Research Center, Laurel, Maryland 20708, USA.

J. Alan YEAKLEY, Department of Environmental Science and Management, Portland State University, PO Box 751, Portland, Oregon 97207, USA.

\begin{abstract}
While diverse, native riparian vegetation provides important functions, it remains unclear to what extent these assemblages can persist in urban areas, and under what conditions. We characterized forested riparian vegetation communities across an urbanizing metropolitan area and examined their relationships with surrounding land cover. We hypothesized that native and hydrophilic species assemblages would correlate with forest cover in the landscape. For each of 30 sites in the Portland-Vancouver metro area, we recorded vegetation at 1-cm intervals along 3 transects using the line-intercept method. Land cover was characterized at 2 scales: within $500 \mathrm{~m}$ of each site and across the entire watershed. Multivariate analyses were used to evaluate relationships between species composition and land cover patterns. A classification tree was created to determine landscape predictors of riparian community type. Results indicated a strong relationship between watershed land cover and vegetation diversity and structural complexity. Our hypothesis of native species association with landscape forest cover in urban riparian areas was supported, but we found no clear relationship between land cover and wetland indicator status. Our results suggest that high watershed forest cover (at least $15 \%$ ) may enable the persistence of functionally diverse, native riparian vegetation communities in urban landscapes.

Keywords: Pacific Northwest, plant diversity, plant ecology, riparian forest, urban ecology, urban watersheds.
\end{abstract}

Résumé: Lorsque diversifiée, la végétation riveraine indigène remplit des fonctions importantes, mais on ne sait pas dans quelle mesure et dans quelles conditions ces assemblages peuvent persister en milieu urbain. Nous avons caractérisé les communautés forestières riveraines dans une zone métropolitaine urbanisée et avons examiné les liens avec la couverture des sols environnants. Notre hypothèse était que les assemblages d'espèces indigènes et hydrophiles seraient corrélés avec la couverture forestière du paysage. Pour chacun des 30 sites situés dans la zone métropolitaine de Portland-Vancouver, des données sur la végétation ont été notées à intervalles de $1 \mathrm{~cm}$ le long de 3 transects selon la méthode d'échantillonnage linéaire. La couverture des sols a été caractérisée à 2 échelles, à l'intérieur de $500 \mathrm{~m}$ du site et dans l'ensemble du bassin versant. Des analyses multivariées ont été utilisées pour évaluer les liens entre la composition en espèces et les patrons de couverture du sol. Un arbre de classification a été créé pour déterminer les éléments du paysage pouvant prédire le type de communauté riveraine. Les résultats ont indiqué un fort lien entre la couverture des sols dans le bassin versant et la diversité et la complexité structurale de la végétation. Notre hypothèse d'un lien entre les espèces indigènes et la couverture forestière du paysage dans les zones riveraines en milieu urbain était supportée, mais nous n'avons pas trouvé de lien clair entre la couverture du sol et le statut d'indicateur d'hydromorphie. Nos résultats suggèrent qu'une couverture forestière élevée (au moins $15 \%$ ) dans le bassin versant peut permettre la persistance de communautés de plantes indigènes riveraines diversifiées sur le plan fonctionnel dans les paysages urbanisés.

Mots-clés : bassins versants en milieu urbain, diversité végétale, écologie végétale, forêt riveraine, Nord-ouest du Pacifique.

Nomenclature: Hitchcock \& Cronquist, 1973; USDA NRCS, 2013.

\section{Introduction}

The vegetation of riparian forest communities provides many critical functions in urban areas (Groffman et al., 2003; Newham, Fellows \& Sheldon, 2011). These assemblages modulate runoff from uplands, provide flood buffering capacity (Tabacchi et al., 2000), pollution amelioration (Sweeney et al., 2004), energy for stream

${ }^{1}$ Rec. 2013-08-28; acc. 2014-02-19.

Associate Editor: Hugo Asselin.

${ }^{2}$ Author for correspondence.

DOI 10.2980/20-4-3635 organisms (Nakano \& Murakami, 2001), and stream temperature regulation (Johnson \& Jones, 2000). They also offer unique habitat (Gregory et al., 1991; Naiman \& Decamps, 1997) and recreation opportunities. Diverse, native riparian assemblages, however, are disappearing from urban areas (Moffatt, McLachlan \& Kenkel, 2004; Loewenstein \& Loewenstein, 2005; Ozawa \& Yeakley, 2007). It is unclear to what extent these assemblages can persist in urban settings, and under what conditions. Our goals were to characterize variation among forested riparian 
vegetation assemblages across the Portland, Oregon and Vancouver, Washington metro area, and to identify relationships between these assemblages and different urban watershed land cover types. A better understanding of these relationships can help improve restoration and maintenance of these ecosystems.

Unlike in rural forests, urban understory communities are often dominated by woody, annual, and animaldispersed species (Moffatt \& McLachlan, 2004). Flood- and shade-intolerant species are also common in these areas (Groffman et al., 2003; Burton, Samuelson \& Mackenzie, 2009), as are non-natives (Cadenasso \& Pickett, 2001; Duguay, Eigenbrod \& Fahrig, 2007). While these vegetation types are more common in urban than rural riparian forests, it is unclear how their prevalence varies across an urban environment in response to different types of land cover.

Habitat fragmentation is one potential driver of riparian vegetation patterns in urban areas. Urban habitat patches are often highly fragmented (Irwin \& Bockstael, 2007), potentially reducing seed dispersal among patches (Ehrlen \& Erikkson, 2000; McEuen \& Curran, 2004) and altering habitat conditions within patches. The prevalence of shadeintolerant species in urban forest fragments is likely due to the great extent of surrounding open habitat and lack of forest interior (Moffatt, McLachlan \& Kenkel, 2004). Forest fragmentation can also facilitate establishment by non-native species common to the surrounding landscape (Lin et al., 2006).

Landscape urbanization can also cause numerous changes throughout the watershed, affecting stream hydrology, water quality, stream and riparian habitat, and ultimately riparian vegetation assemblages (Allan, 2004; Meek, Richardson \& Mucina, 2010). Soil alteration affects transport of water and sediment to streams, altering stream flows, sediment loads, and erosion (Cooper et al., 2013). Urban impervious surfaces can lead to channel down-cutting, infrequent overbank flow, reduced infiltration, and higher pollutant loads (Groffman et al., 2003; Walsh et al., 2005; Cooper et al., 2013). While irrigation and sewage treatment can increase summer flows in some areas, urban surfaces typically enhance the seasonality of stream flow in Mediterranean and similar climates, resulting in higher winter peak flows and even lower dry season flows (Konrad \& Booth, 2005; Cooper et al., 2013). Because of these changes, many urban riparian areas support very different vegetation assemblages than rural riparian areas (Groffman et al., 2003; Burton, Samuelson \& Mackenzie, 2009).

While many studies report strong effects of urbanization on vegetation (Moffatt \& McLachlan, 2004; Loewenstein \& Loewenstein, 2005; Burton \& Samuelson, 2008), others suggest that native, diverse riparian areas can exist in urban settings. Oneal and Rotenberry (2008) found that riparian community composition did not vary substantially along a development gradient in California. Likewise, Guntenspergen and Levenson (1997) and Porter, Forschner, and Blair (2001) found no predictable patterns in vegetation composition related to land use. Others have shown equal (Hutmacher et al., 2013) or higher (Wania, Kuhn \& Klotz, 2006; McKinney, 2008; Meek, Richardson \& Mucina, 2010) species richness in urban areas than rural. Tabacchi and Planty-Tabacchi (2005) found high riparian richness in a human-dominated landscape at all scales considered. These studies suggest that some native, diverse vegetation assemblages are resilient to urban development.

While there is evidence that land cover immediately adjacent to a riparian area affects vegetation (Pennington, Hansel \& Gorchov, 2010; Fernandes, Aguiar \& Ferreira, 2011), it is unclear how urban cover types at broader scales affect these assemblages. Riparian species are thought to be influenced by a mix of landscape and local variables (Sarr \& Hibbs, 2007; Baker \& Wiley, 2009), so considering urban influences at a broad scale is important. We sought to gain insight into what broad-scale urban landscape characteristics were needed to maintain diverse native riparian forest assemblages. We hypothesized that riparian assemblages with high cover by native and hydrophilic species would be associated with high forest cover and low development cover in the surrounding landscape. Our analysis focused on the community composition of riparian areas. Better understanding of how landscape factors correspond to the maintenance of diverse and native riparian vegetation assemblages can inform urban land use planning and policy development that will help conserve these ecosystems.

\section{Methods}

\section{Site SELECTION}

This study took place in the Portland, Oregon and Vancouver, Washington metro area. Portland and its metropolitan area have a strong history of conservation of parks and natural areas, with a regional government that maintains an urban growth boundary and works to conserve the region's natural areas (Metro, 2013). The metro region has an average annual temperature of $12.5^{\circ} \mathrm{C}$, with an August average of $20.8{ }^{\circ} \mathrm{C}$ and a December average of $4.7{ }^{\circ} \mathrm{C}$. Annual rainfall is $92 \mathrm{~cm}$ per year, with over $70 \%$ of rain occurring November through April (Rockey, 2012). Thirty forested riparian sites were randomly selected for study in the summer of 2011 (Figure 1). In the Portland metro area in Oregon we defined all sites within the urban growth boundary as urban. In the Vancouver, Washington area riparian sites were considered for study if they were within 30 minutes' driving from downtown Portland and within Clark County, the county that contains the city of Vancouver. All sites considered for selection had perennial flow, first to third stream order, at least a 100-m long accessible stream segment, and canopy cover along the 100-m segment. ArcGIS version 9.3.1 (ESRI, 2009) was used to identify qualified sites. We used stream layers from the National Hydrography Dataset (USGS, online) for the Portland metro area and Vancouver and land cover layers from the Metro 2007 Regional Land Information System (Metro Data Resource Center, 2013). We used a robust randomization procedure to ensure good representation of streams typical to the metro area. Random numbers were assigned to each stream that met selection criteria, and 40 stream sites were selected, including sites on both publicly and privately owned land. In field visits we determined that 9 of those 40 sites had active restoration projects, and were therefore not suitable for study. Additionally, we removed 1 site due to insufficient canopy cover. Data were collected from the remaining 30 sites. 


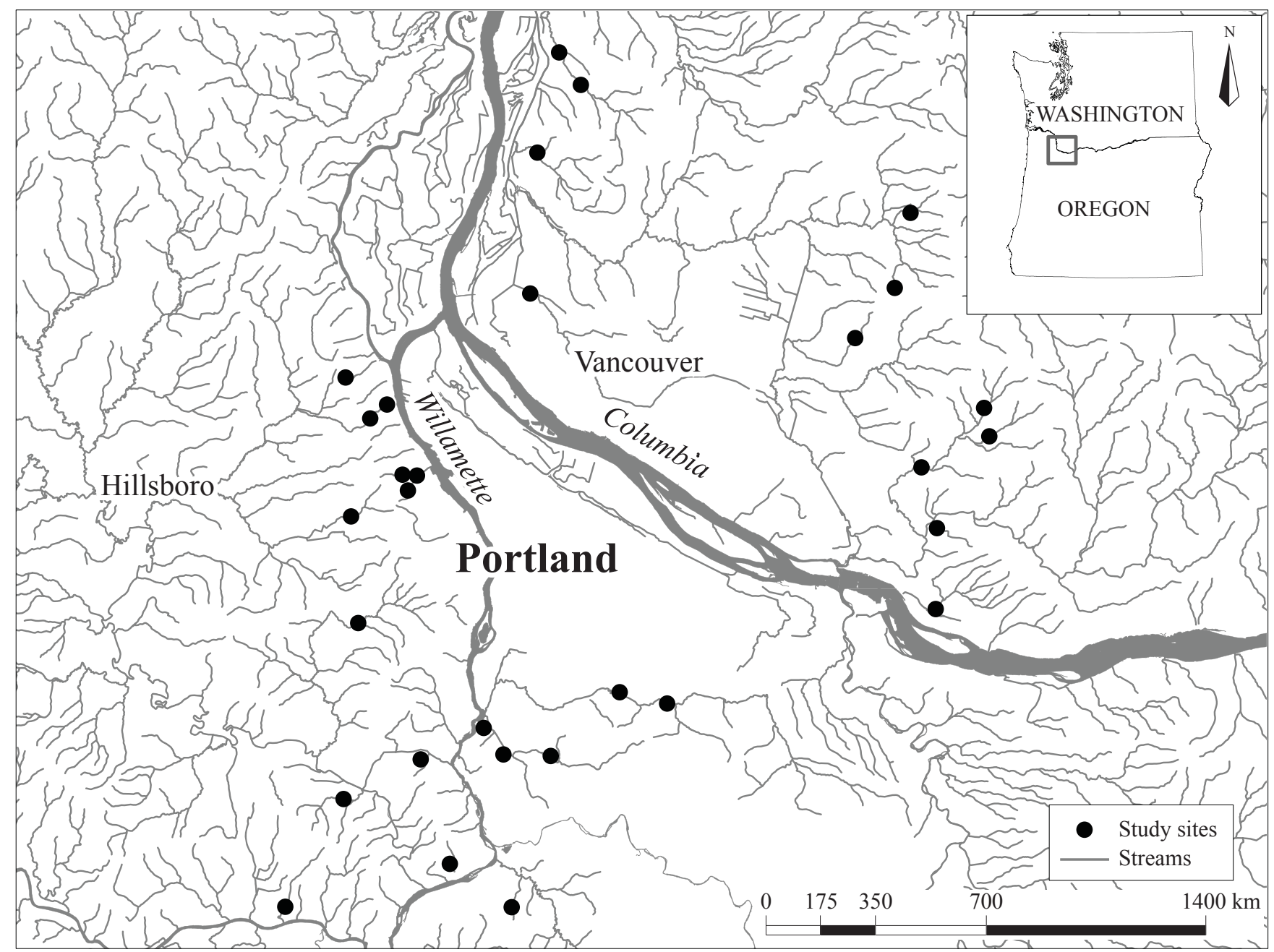

FIGURE 1. Thirty study sites in the Portland-Vancouver metro area. Riparian sites were randomly selected on public and private property on both the Oregon and Washington sides of the Columbia River. All sites were on first- to third-order streams, had some canopy cover, and had not been actively managed. Map centre is at $45^{\circ} 35^{\prime} 46^{\prime \prime} \mathrm{N}, 122^{\circ} 36^{\prime} 10^{\prime \prime} \mathrm{W}$.

\section{VEGETATION SURVEY}

We used the line-intercept method to sample vegetation. Three transects were established in each site on 1 stream bank, spaced $25 \mathrm{~m}$ apart and perpendicular to the stream reach. The first transect was placed at the midpoint of the site. Transects were at least $5 \mathrm{~m}$ in length and spanned from the top of the stream bank to the smaller of either the termination of accessible riparian area or $60 \mathrm{~m}$ measured laterally across the slope. Vegetation in all strata was identified along the transects. The length of transect covered by each plant species was recorded to the nearest centimetre. We identified vegetation to the species level based on Pojar and MacKinnon (1994) and Hitchcock and Cronquist (1973). Species richness and Shannon diversity were calculated for each site (Shannon \& Weaver, 1949). Species were categorized by native status, structural class (tree, shrub, herb), and wetland indicator status (WIS). WIS categories used were obligate upland (UPL), facultative upland (FACU), facultative (FAC), facultative wetland (FACW), and obligate wetland (OBL). The USDA PLANTS database (USDA NRCS, 2013) was used to determine WIS categories for each species. Species with no WIS listing (NL) in the PLANTS database were considered unlikely to occur in wetlands and grouped with UPL species for analysis. These vegetation metrics were recorded as percent cover, which ranged from $0 \%$ to well over $100 \%$ due to the dense, multi-layered nature of the vegetation.

\section{WATERSHED CHARACTERISTICS}

Watershed boundaries were delineated using ArcGIS (ESRI, 2009) from a point $500 \mathrm{~m}$ downstream from the study site. Land cover data from 2006 in the National Land Cover Database (NLCD; Fry et al., 2011) were used to determine composition of cover types in the landscape. The percentages of each cover type defined in the NLCD were recorded at 2 scales, within a 500-m buffer around each site and in the entire watershed. Land cover types included different urban development intensities, agricultural land, and forest cover, among other types (Table I). At the watershed level total impervious surface area, also provided in the NLCD, derived from Landsat imagery at a resolution of $30 \mathrm{~m}$ (Table I), was calculated.

\section{DATA ANALYSIS}

Data analysis was completed using $\mathrm{R}$ version 2.15 .2 (R Development Core Team, 2012). Because of the large 
TABLE I. Landscape variables measured within a 500-m buffer and within the entire watershed. "W" in the variable code indicates the variable was measured at the watershed scale; "B" indicates that it was measured at the 500-m buffer scale. All land cover data are from the 2006 National Land Cover Database (NLCD). The land cover classification is based on Landsat satellite data and has 30-m resolution (Fry et al., 2011). Mean, minimum, and maximum cover recorded at the watershed level is reported. Development density variables are based on percentage impervious surface area. Total impervious surface area (TIA) within the watershed is also shown.

\begin{tabular}{|c|c|c|c|c|}
\hline Variable code & Variable description & $\begin{array}{l}\text { Mean cover } \\
(\%)\end{array}$ & $\begin{array}{l}\text { Min cover } \\
(\%)\end{array}$ & $\begin{array}{l}\text { Max cover } \\
\quad(\%)\end{array}$ \\
\hline W.Water, B.Water & Open water; areas of open water with $\leq 25 \%$ soil or vegetation & 0.01 & 0 & 0.28 \\
\hline W.Open, B.Open & Open development; some construction, mostly vegetation, $<20 \%$ total impervious cover & 8 & 0.01 & 26 \\
\hline W.Lo, B.Lo & Low density development; $20-49 \%$ impervious cover, often single-family housing & 20 & 0 & 60 \\
\hline W.Md, B.Md & Medium density development; $50-79 \%$ impervious cover, often single-family housing & 8 & 0 & 40 \\
\hline W.Hi, B.Hi & $\begin{array}{l}\text { High density development; } 80-100 \% \text { impervious cover; } \\
\text { apartments, commercial and industrial areas }\end{array}$ & 2 & 0 & 17 \\
\hline W.Dec, B.Dec & Deciduous forest; trees $>5 \mathrm{~m}$ tall make up $\geq 20 \%$ vegetation, $\geq 75 \%$ of trees are deciduous & 5 & 0 & 19 \\
\hline W.For, B.For & $\begin{array}{l}\text { Evergreen forest; trees }>5 \mathrm{~m} \text { tall make up } \geq 20 \% \text { vegetation, } \geq 75 \% \text { of trees are evergreen, } \\
\text { canopy is never without green foliage }\end{array}$ & 18 & 0 & 65 \\
\hline W.Mix, B.Mix & $\begin{array}{l}\text { Mixed forest; trees }>5 \mathrm{~m} \text { tall make up } \geq 20 \% \text { vegetation, } \\
\text { neither deciduous nor evergreen trees make up } \geq 75 \% \text { trees }\end{array}$ & 16 & 0 & 57 \\
\hline W.Shrub, B.Shrub & Scrub/shrub; shrubs $<5 \mathrm{~m}$ tall make up $\geq 20 \%$ vegetation & 6 & 0 & 39 \\
\hline W.Herb, B.Herb & Grassland/herbaceous - graminoid or herbaceous vegetation make up $>80 \%$ of vegetation & 2 & 0 & 12 \\
\hline W.Pas, B.Pas & Pasture/hay; grasses or legumes planted grazing or hay make up $>20 \%$ vegetation & 12 & 0 & 58 \\
\hline W.Crop, B.Crop & Cultivated crops; crop vegetation make up $>20 \%$ vegetation & 1 & 0 & 12 \\
\hline W.Wet, B.Wet & $\begin{array}{l}\text { Woody wetlands; forest/shrubland make up }>20 \% \text { vegetation, } \\
\text { soil or substrate periodically saturated with water }\end{array}$ & 1 & 0 & 5 \\
\hline W.Emer, B.Emer & $\begin{array}{l}\text { Emergent herbaceous wetlands - perennial herbaceous vegetation make up }>80 \% \text { vegetation, } \\
\text { soil periodically saturated or covered with water }\end{array}$ & 0.1 & 0 & 1 \\
\hline W.Imp & Total impervious surface area (measured as percent cover) & 15 & 12 & 54 \\
\hline
\end{tabular}

number of both explanatory (land cover) and response (vegetation characteristics) variables, we decided to use a multivariate approach. We used non-metric multidimensional scaling (NMDS) to characterize riparian vegetation community similarity among sites. The ordination was based on rank-similarity of sites using the Bray-Curtis index. Species cover data were square-root transformed to reduce NMDS stress. The square root transformation was used to preserve the information in species of low abundance in the transects (e.g., Magee, Ringold \& Bollman, 2008). Because of the apparent arrangement of sites in distinct clusters, sites were divided into 3 groups for further analysis. Partitioning around medoids (PAM) was used to classify sites into 3 groups based on riparian community similarity (e.g., Hanzlik \& Gerowitt, 2011; Puşcaş $\&$ Choler, 2012). PAM partitioned data set objects into clusters by searching in an iterative process for $k$ representative objects, which are the medoids for the clusters. Data objects were then assigned to the nearest representative object, creating $k$ clusters (Kaufman \& Rousseeuw, 1990). We created final cluster groups for further analysis by combining the results of PAM with patterns visible in the NMDS plot. Analysis of similarity (ANOSIM) was used to verify that these 3 groups differed from each other in species composition.

Indicator analysis was conducted using the "indval" function in the package "vegan," (Oksanen et al., 2012) to determine species characteristic of each cluster group. The most appropriate indicator species were those found primarily in a single group and present in most of the sites in that group. The indval method created an index of indicator values, ranking species on specificity and fidelity to group (Dufrêne \& Legendre, 1997). A randomization procedure with 1000 permutations was used to determine significant $(P<0.05)$ indicator values. Differences among cluster groups in cover by native and non-native species, wetland indicator classes, and structural classes were identified using Kruskal-Wallis and pairwise Wilcoxon rank-sum tests with the Bonferroni correction for multiple tests.

Relationships between land cover and riparian vegetation were identified by fitting landscape vectors to the NMDS ordination. The R function "envfit" was used with 1000 permutations to fit landscape vectors to the NMDS ordination and determine which vectors were significantly $(P<0.05)$ associated with NMDS space (Strohbach, Audorff \& Beierkuhnlein, 2009). We then created a classification tree using the package "rpart" (Therneau, Atkinson \& Ripley, 2012) to determine the best landscape predictors of a site's cluster group affinity.

\section{Results}

Across all 30 sites mean transect length was $16.8 \pm 15.3 \mathrm{~m}$ (mean $\pm \mathrm{SD})$. A total of 82 vegetation types were identified to species level, including 65 native and 17 non-native species. Site species richness ranged from 10 to 42 , with a mean of $20 \pm 8$. Shannon diversity ranged from 1.79 to 2.62 , with a mean of $2.24 \pm 0.22$.

The NMDS plot showed a wide distribution of sites based on species composition (Figure 2), indicating variation in riparian vegetation composition among sites. NMDS stress was 0.21 , and because a third dimension did not substantially improve the stress value, we used only the first 2 dimensions. PAM broke sites into 3 groups roughly matching their location on the NMDS ordination. Three of the sites were poorly matched by PAM and were reassigned to more appropriate groups according to their position in NMDS space. ANOSIM results confirmed that these final 3 cluster groups differed significantly $(P<0.05)$ in species composition.

Between 2 and 11 species with significant $(P<0.05)$ indicator values were found for each of the 3 cluster groups (Table II). The first group was termed the "Forest" group, 


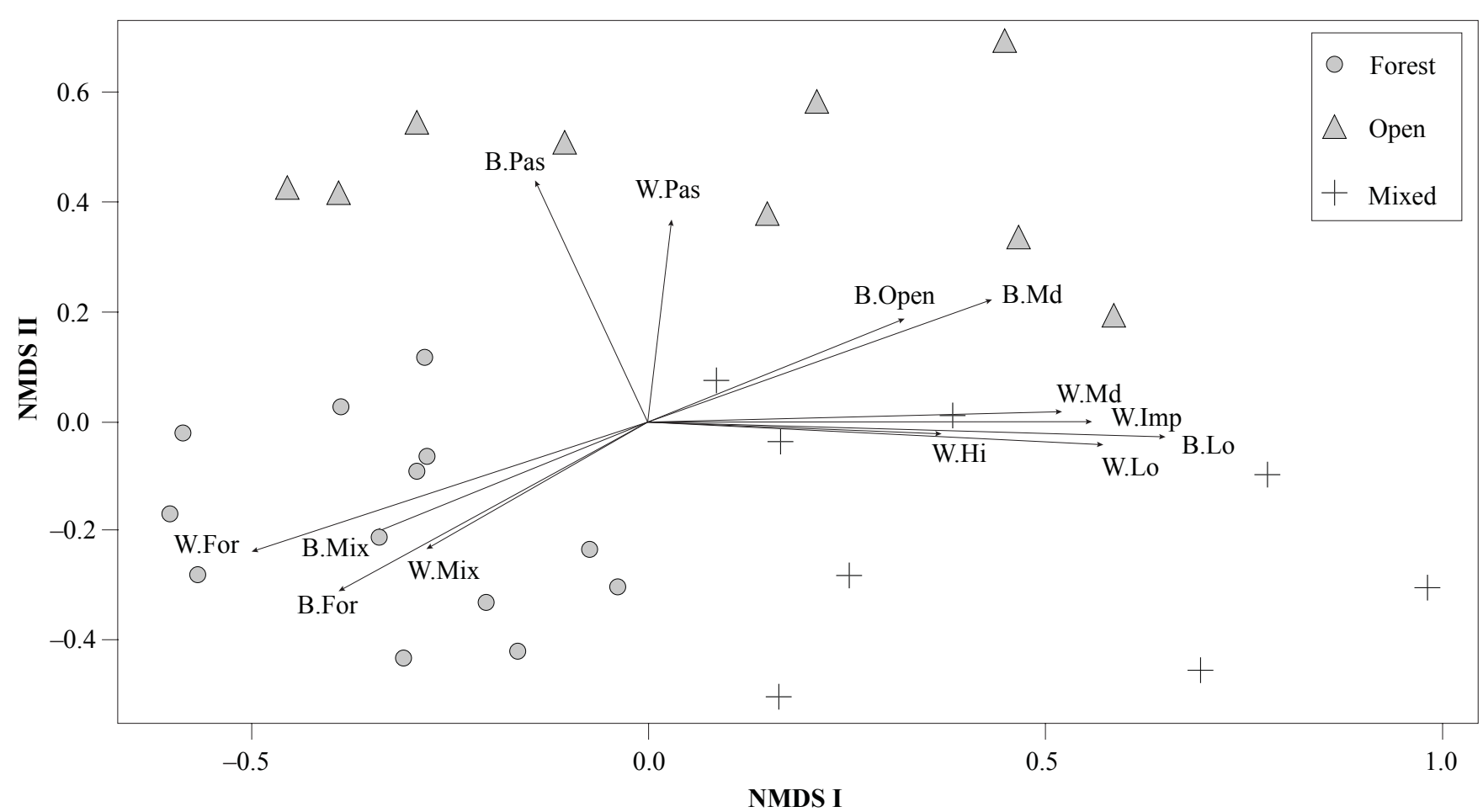

FIGURE 2. NMDS plot of study sites with associated landscape vectors. The ordination of sites was based on riparian vegetation similarity. Symbols indicate the cluster group to which each site belongs, determined by partitioning around medoids (PAM) and position in NMDS space. Overall, there is a wide distribution of sites in NMDS space, indicating variation in riparian vegetation composition. Forest sites (circles) clustered a bit more tightly than sites in Open (triangles) and Mixed (crosses). Vectors represent the association of landscape variables with distribution of sites in ordination space. Only landscape vectors significantly associated with the ordination $(P<0.05)$ are shown. Forest sites are associated with high landscape forest cover. Open sites appear to be associated with agricultural cover and urban development at the 500-m-buffer scale (B.Open, B.Md). Mixed sites are associated with urban development and watershed impervious surface area. NMDS stress $=0.21$. Definitions of landscape variables are shown in Table I.

TABLE II. Significant indicator species for cluster groups. A minimum of 2 species with significant $(P<0.05)$ indicator values were found for each cluster group. Species with the highest values were the best indicators. The native tree T. heterophylla, subcanopy species $A$. circinatum, and species typical of a forest understory were Forest indicators. The fast-growing tree $A$. rubra and non-native $P$. arundinacea were indicators for Open. Two native trees and 2 non-native shrubs were Mixed indicators. Wetland indicator status codes: FAC = facultative; FACU = facultative upland; FACW = facultative wetland; NL = not listed (treated as upland). Wetland indicator status classifications from the USDA PLANTS database (USDA NRCS, 2013).

\begin{tabular}{|c|c|c|c|c|c|}
\hline Species & Native status & Structure & Wetland indicator status & Indicator value (\%) & $P$-value \\
\hline \multicolumn{6}{|l|}{ Forest } \\
\hline Acer circinatum & Native & Tree & FAC & 88 & 0.00 \\
\hline Polystichum munitum & Native & Herb & FACU & 73 & 0.00 \\
\hline Vaccinium parvifolium & Native & Shrub & NL & 63 & 0.00 \\
\hline Gaultheria shallon & Native & Shrub & FACU & 54 & 0.01 \\
\hline Adiantum aleuticum & Native & Herb & FAC & 53 & 0.00 \\
\hline Trillium ovatum & Native & Herb & FACU & 52 & 0.01 \\
\hline Vancouveria hexandra & Native & Herb & NL & 48 & 0.04 \\
\hline Prosartes hookeri & Native & Herb & NL & 48 & 0.03 \\
\hline Maianthemum racemosum & Native & Herb & FAC & 44 & 0.01 \\
\hline Tsuga heterophylla & Native & Tree & FACU & 44 & 0.01 \\
\hline Polypodium glycyrrhiza & Native & Herb & $\mathrm{NL}$ & 44 & 0.04 \\
\hline \multicolumn{6}{|l|}{ Open } \\
\hline Alnus rubra & Native & Tree & FAC & 51 & 0.01 \\
\hline Phalaris arundinaceae & Non-native & Herb & FACW & 48 & 0.01 \\
\hline \multicolumn{6}{|l|}{ Mixed } \\
\hline Fraxinus latifolia & Native & Tree & FACW & 57 & 0.00 \\
\hline Hedera helix & Non-native & Shrub & NL & 53 & 0.01 \\
\hline Thuja plicata & Native & Tree & FAC & 47 & 0.05 \\
\hline Ilex aquifolium & Non-native & Shrub & NL & 47 & 0.02 \\
\hline
\end{tabular}


and had a mean species richness of $27( \pm 7)$. Indicator species for this group included Tsuga heterophylla (western hemlock), a mature forest species, and the subcanopy species Acer circinatum (vine maple). Three fern and 3 lily species were also indicators for the Forest group, in addition to other herbs and shrubs typical of forest understory. The second group had a mean species richness of $14( \pm 3)$, and was characterized by the native tree Alnus rubra (red alder) and non-native grass Phalaris arundinacea (reed canarygrass). Both of these species occur in open areas, so this group was termed the "Open" group. Two native trees, evergreen Thuja plicata (western redcedar) and deciduous Fraxinus latifolia (Oregon ash), and 2 non-native shrubs, Hedera helix (English ivy) and Ilex aquifolium (English holly), were indicators for the third group. Due to the mixture of native and non-native species, shade tolerances, and moisture requirements in this group, it was termed the "Mixed" group. Mixed had a mean species richness of $17( \pm 3)$.

\section{COVER BY VEGETATION TYPE}

Kruskal-Wallis tests indicated significant differences $(P<0.05)$ among cluster groups in diversity metrics, native and non-native cover, and cover by different
WIS and structural categories. Wilcoxon tests showed that Forest sites had significantly higher species richness than Open and Mixed sites and higher Shannon diversity than Open sites $(P<0.05)$. Forest sites also had significantly higher native cover than Open and Mixed sites $(P<0.001)$ and significantly lower non-native cover than Mixed sites $(P<0.05$; Figure 3a,b). Sites in Open and Mixed groups did not differ significantly from each other in diversity metrics or native and non-native cover.

Cover by 3 wetland indicator classes, FACU, FAC, and $\mathrm{FACW}$, varied among cluster groups. There were no significant differences in cover by UPL species, and too few occurrences of OBL species to analyze. Forest sites had significantly higher FACU cover $(P<0.001)$ and significantly lower FACW cover $(P<0.05)$ than Open sites. Forest sites also had higher FAC cover than Mixed sites $(P<0.05)$.

The structural composition of Forest differed from the composition of Open and Mixed. Forest sites had significantly higher tree cover than Open sites $(P<0.05$; Figure $3 \mathrm{c}$ ) and significantly higher herbaceous cover than Mixed sites $(P<0.001$; Figure $3 \mathrm{e})$. Shrub cover appeared to be lower in Forest than Mixed sites (Figure 3d), but the difference between the 2 groups was not statistically significant.
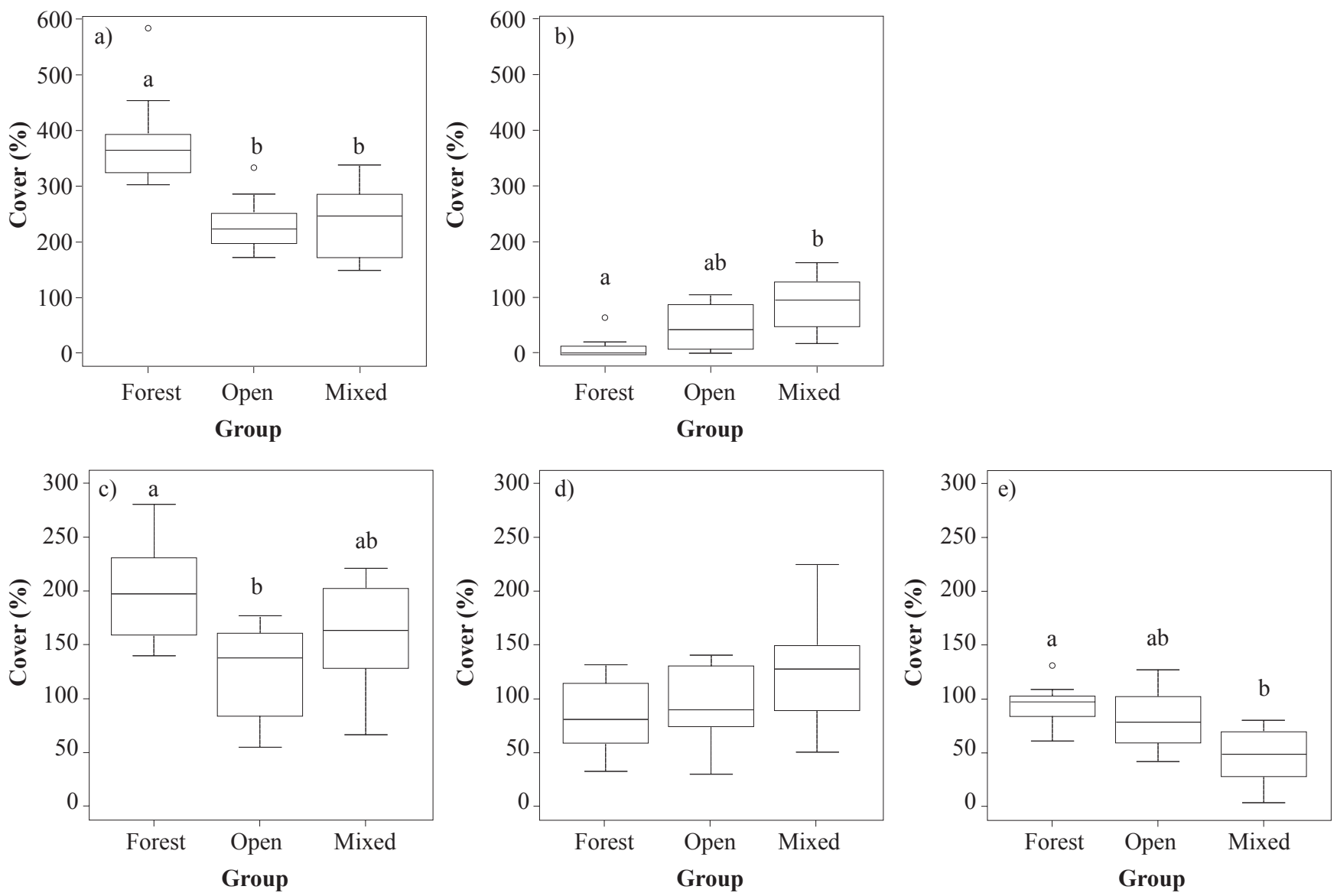

FiguRE 3. Native and non-native cover by cluster group (a and b); Tree, shrub, and herb cover by cluster group (c, d, and e). Different letters indicate significant $(P<0.05)$ differences between groups in pairwise Wilcoxon tests. a) Forest had significantly higher native cover than Open and Mixed. b) Mixed had significantly higher non-native cover than Forest. Open was not significantly different in non-native cover from Forest or Mixed. c) Forest had significantly higher tree cover than Open. d) Forest had the lowest shrub cover and Mixed the highest, although differences were not statistically significant $(P>0.05)$. e) Forest had significantly higher herb cover than Mixed. 
WATERSHED CHARACTERISTICS AND ASSOCIATION WITH RIPARIAN VEGETATION COVER

A total of 13 land cover variables had significant $(P<0.05)$ relationships with NMDS space, indicating a relationship with vegetation composition in the sites (Figure 2). Variables measured at both the watershed and 500 -m-buffer scales were significant. At the watershed scale, 3 of the 4 urban development levels (low-, medium-, high-intensity), evergreen forest, mixed forest, pasture/hay, and impervious surface cover were significant $(P<0.05)$. At the 500-m-buffer scale open-, low-, and medium-intensity development, evergreen forest, and pasture/hay were significant $(P<0.05)$. Forest group sites were strongly associated with high landscape forest cover, both at the watershed scale and within the $500-\mathrm{m}$ buffer. Open and Mixed sites were positively associated with urban, agriculture, development, and impervious surface in the landscape and negatively with forest cover. Wilcoxon tests confirmed differences between Forest and the other cluster groups in surrounding landscape composition. While Wilcoxon tests did not show significant differences between Open and Mixed sites for landscape metrics, landscape vectors fit to the NMDS by 'envfit' suggested that at least some Open sites were surrounded by more agriculture than Mixed sites (Figure 2).

The classification tree confirmed the importance of watershed forest cover (Figure 4), indicating it as the strongest predictor of cluster group affinity. All 13 Forest sites were distinguished from Open and Mixed sites by watershed forest cover of at least 15\%. Open and Mixed sites all had watershed forest cover lower than $15 \%$ and were distinguished from each other by watershedlevel open development and 500-m-buffer-level low-intensity development.

\section{Discussion}

Landscape forest cover played a significant role in predicting vegetation community type in urban riparian areas in our study. Similar to other studies (Lowenstein \& Lowenstein, 2005; Burton \& Samuelson, 2008), we found the most species-rich Forest communities in sites with high surrounding forest cover. The classification tree indicated that at least $15 \%$ watershed forest cover was the determinant of Forest communities. These sites had higher native cover and greater structural complexity than Open or Mixed sites, and very low or no non-native cover. The high mean native cover in these assemblages (Figure 3a) is not surprising given the shade-tolerant nature of these forest species. These sites were characterized by species representative of forest interior habitat, including several lily and fern species and shade-tolerant shrubs. Forest cover may promote the persistence of these species by maintaining low understory light levels, inhibiting encroachment by faster growing, shade-intolerant species (Everson \& Boucher, 1998; Angiolini et al., 2011). Forest understory species are also generally poor dispersers over a long distance and are likely to be affected by habitat fragmentation (Honnay et al., 2002; Kolb \& Diekmann, 2005;

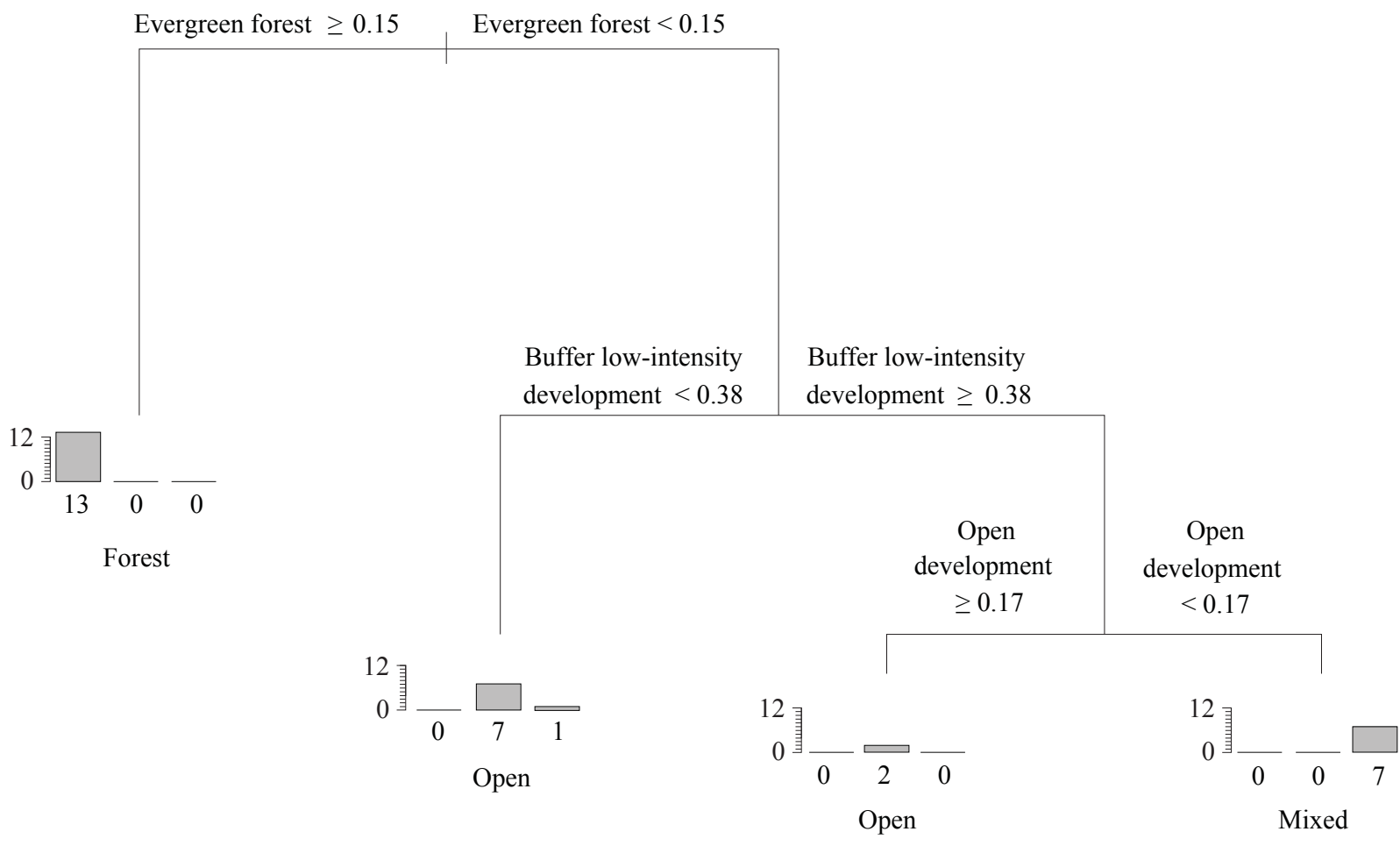

FiguRE 4. Classification of sites by land cover variables. The classification tree had a misclassification rate of 3.3\%, with 1 Mixed site classified as an Open site. Bar charts indicate the number of sites classified in each group by the tree (Forest/Open/Mixed). Watershed evergreen forest was the first predictor of cluster group, separating out all 13 Forest sites with cover of at least $15 \%$. Open and Mixed sites were distinguished from each other by low-intensity development within the 500-m buffer and open development within the watershed. 
Pearson \& Dawson, 2005). Forest connectivity may be a requirement for viable populations of these understory species; forest discontinuities within $1 \mathrm{~km}$ of a patch have been found to affect forest specialist species (Herault \& Honnay, 2005). Likewise, our results suggest that at the scale of the entire watershed, forest continuity affects these species. However, while some other studies have found weaker relationships between riparian vegetation and land cover at broad scales than at local scales (Allan, Erickson \& Fay, 1997; Fernandes, Aguiar \& Ferreira, 2011), our results suggest that watershed-level land cover patterns are correlated with riparian vegetation patterns. Studies of stream organisms and water quality have also found watershedlevel land cover patterns to be important variables (Houser, Mulholland \& Maloney, 2005; Lorenz \& Feld, 2013), and it appears from this study that those relationships may extend to riparian vegetation assemblages as well. These findings are consistent with Nucci et al. (2012), who concluded that a multiscale perspective is appropriate when considering the controls on riparian vegetation.

Our hypothesis of largely native riparian assemblages in watersheds with high forest cover was supported by results. Native cover was strongly and positively associated with landscape forest cover and negatively with watershed development and agriculture. Non-native cover was positively associated with surrounding development and negatively with forest cover. Magee, Ringold, and Bollman (2008) also found lowest cover by alien species in watersheds with closed forest compared to other rural land cover types. However, urban riparian areas and land cover types were not included in their Eastern Oregon study. Our results are also consistent with findings of high non-native cover in riparian areas immediately surrounded by development, but these urban studies have generally not considered the effects of land cover at broader watershed scales (Cadenasso \& Pickett, 2001; Lin et al., 2006; Duguay, Eigenbrod \& Fahrig, 2007).

Contrary to our expectations, high FACW cover was found in Open and Mixed sites, positively associated with agriculture and development and negatively with forest cover in the landscape. These results vary from findings of greater prevalence of flood-intolerant species in more urban sites in other studies (Groffman et al., 2003; Burton, Samuelson \& Mackenzie, 2009). It is important to note, however, that the 2 most abundant FACW species, $P$. arundinacea and $F$. latifolia, indicator species for Open and Mixed respectively, have medium and low shade tolerance, and are not typical of dense forest (USDA NRCS, 2013). It is possible that the high cover by these hydrophilic species in Open and Mixed sites is driven by the light environment in these more urban and agricultural watersheds rather than the moisture regime. It is also possible that the expected trends would emerge in a study including watersheds with more cover by high-intensity development. The low amount of surrounding cover by high-intensity development is also likely the reason that, as with Hutmacher et al. (2013), we found no relationship between the density of urban development and non-native riparian cover.
Our results suggest that local and landscape factors associated with minimal riparian cover by Hedera helix and other non-native shrubs are necessary for protecting structural diversity in riparian areas. Forest, with the highest watershed forest cover, was the only group to have indicator species representative of all 3 structural groups. Higher tree cover in Forest than in Open and Mixed groups (Figure 3a) is consistent with Salinas and Casas (2007), who found lower woody cover and diversity in riparian areas with increasing human impacts. However, the significantly higher herbaceous cover in Forest than Mixed (Figure 3e) is in sharp contrast to Guntenspergen and Levenson (1997), who found no difference in understory herbaceous composition along a rural-urban gradient in Wisconsin. In our study, it is possible that the difference between Forest and Mixed sites in herbaceous cover reflects a trade-off between understory herb and non-native shrub cover. Mixed sites had high cover by invasive $H$. helix, an indicator species for this group. $H$. helix is a moderately fast-growing vine (USDA NRCS, 2013) that can smother native, herbaceous species on the forest floor (Dlugosch, 2005). Similarly, Vidra, Shear, and Wentworth (2006) found that non-native vines were negatively correlated with the presence of native forest herbaceous species in Northern California. H. helix may be contributing to reduced species richness and structural complexity in Open and Mixed sites compared to Forest sites, as was found in Seattle parks (Dlugosch, 2005). Structural complexity is an important habitat component (Banville \& Bateman, 2012), and results suggest that control of $H$. helix and other non-native shrubs is required for its maintained presence. Our results indicate that cover by non-native shrubs is lowest where there is highest watershed forest cover. Riparian sites in such watersheds with significant forest cover should be prioritized for conservation.

\section{Conclusion}

Our results show that functionally diverse, native riparian forest assemblages can exist in urban landscapes in certain situations. Watershed forest cover appears to be the most important condition for these assemblages, with structurally diverse, native, forest understory species present in urban riparian areas with at least $15 \%$ watershed forest cover. While the relationship between diverse, native riparian assemblages and landscape forest cover is not surprising, as far as we know this is the first study to suggest that, even for sites within an urban area and subject to urban disturbances, forest cover at the watershed scale can serve to protect these assemblages. Within the urban environment, riparian management and research has largely focused on near-stream variables and buffer strips (Richardson, Naiman \& Bisson, 2012), but our results indicate that to maintain diverse riparian forest assemblages and corresponding functions and services, land cover at the broader watershed level should also be considered. As urbanization continues to increase, maintaining as much forest cover as possible in watersheds should be emphasized. Prioritization of large parks, natural areas, and undeveloped forests in watersheds at urban edges may allow cities to better sustain the substantial ecosystem services provided by natural, functionally diverse riparian areas. 


\section{Acknowledgements}

Primary funding support was provided by an American Recovery and Reinvestment Act grant from the United States Forest Service Pacific Northwest Research Station. Additional support came from a National Science Foundation GK-12 Doctoral Fellowship for C. von Behren. We are grateful to S. Kidd and Y. Pan for assistance with statistical analysis, field technicians J. Herrera, B. Burton, S. Zhao, M. Mao, and W. Kerney. We thank two anonymous reviewers and $\mathrm{H}$. Asselin for constructive comments that improved the manuscript.

\section{Literature cited}

Allan, J. D., 2004. Landscapes and riverscapes: The influence of land use on stream ecosystems. Annual Review of Ecology, Evolution, and Systematics, 35: 257-284.

Allan, J. D., D. Erickson \& J. Fay, 1997. The influence of catchment land use on stream integrity across multiple spatial scales. Freshwater Biology, 37: 149-161.

Angiolini, C., A. Nucci, F. Frignani \& M. Landi, 2011. Using multivariate analyses to assess effects of fluvial type on plant species distribution in a Mediterranean river. Wetlands, 31: 167-177.

Baker, M. E. \& M. J. Wiley, 2009. Multiscale control of flooding and riparian forest composition in lower Michigan, U.S.A. Ecology, 90: 145-159.

Banville, M. J. \& H. L. Bateman, 2012. Urban and wildland herpetofauna communities and riparian microhabitats along the Salt River, Arizona. Urban Ecosystems, 15: 473-488.

Burton, M. L. \& L. J. Samuelson, 2008. Influence of urbanization on riparian forest diversity and structure in the Georgia Piedmont, US. Plant Ecology, 195: 99-115.

Burton, M. L., L. J. Samuelson \& M. D. Mackenzie, 2009. Riparian woody plant traits across an urban-rural land use gradient and implications for watershed function with urbanization. Landscape and Urban Planning, 90: 42-55.

Cadenasso, M. L. \& S. T. A. Pickett, 2001. Effect of edge structure on the flux of species into forest interiors. Conservation Biology, 15: 91-97.

Cooper, S. D., P. S. Lake, S. Sabater, J. M. Melack \& J. L. Sabo, 2013. The effects of land use changes on streams and rivers in Mediterranean climates. Hydrobiologia, 719: 383-425.

Dlugosch, K., 2005. Understory community changes associated with English ivy invasions in Seattle's urban parks. Northwest Science, 79: 53-60.

Dufrêne, M. \& P. Legendre, 1997. Species assemblages and indicator species: The need for a flexible asymmetrical approach. Ecological Monographs, 67: 345-366.

Duguay, S., F. Eigenbrod \& L. Fahrig, 2007. Effects of surrounding urbanization on non-native flora in small forest patches. Landscape Ecology, 22: 589-599.

Ehrlen, J. \& O. Erikkson, 2000. Dispersal limitation and patch occupancy in forest herbs. Ecology, 81: 1667-1674.

ESRI, 2009. ArcGIS Desktop version 9.3.1. Redlands, California.

Everson, D. A. \& B. H. Boucher, 1998. Tree species-richness and topographic complexity along the riparian edge of the Potomac River. Forest Ecology and Management, 109: 305-314.

Fernandes, M. R., F. C. Aguiar \& M. T. Ferreira, 2011. Assessing riparian vegetation structure and the influence of land use using landscape metrics and geostatistical tools. Landscape and Urban Planning, 99: 166-177.
Fry, J., G. Xian, S. Jin, J. Dewitz, C. Homer, L. Yang, C. Barnes, N. Herold \& J. Wickham, 2011. Completion of the 2006 National Land Cover Database for the conterminous United States. Photogrammetric Engineering \& Remote Sensing, 77: 858-864.

Gregory, S. V., F. J. Swanson, W. A. McKee \& K. W. Cummins, 1991. An ecosystem perspective of riparian zones. BioScience, 41: $540-551$.

Groffman, P. M., D. J. Bain, L. E. Band, K. T. Belt, G. S. Brush, J. M. Grove, R. V. Pouyat, I. C. Yesilonis \& W. C. Zipperer, 2003. Down by the riverside: Urban riparian ecology. Frontiers in Ecology and the Environment, 6: 315-321.

Guntenspergen, G. R. \& J. B. Levenson, 1997. Understory plant species composition in remnant stands along an urban-to-rural land use gradient. Urban Ecosystems, 1: 155-169.

Hanzlik, K. \& B. Gerowitt, 2011. The importance of climate, site and management on weed vegetation in oilseed rape in Germany. Agriculture, Ecosystems \& Environment, 141: 323-331.

Herault, B. \& O. Honnay, 2005. The relative importance of local, regional and historical factors determining the distribution of plants in fragmented riverine forests: An emergent group approach. Journal of Biogeography, 12: 2069-2081.

Hitchcock, C. L. \& A. Cronquist, 1973. Flora of the Pacific Northwest. University of Washington Press, Seattle, Washington.

Honnay, O., W. Verheyen, J. Butaye, H. Jacquemyn, B. Bossuyt \& M. Hermy, 2002. Possible effects of habitat fragmentation and climate change on the range of forest plant species. Ecological Letters, 5: 525-530.

Houser, J. N., P. J. Mulholland \& K. O. Maloney, 2005. Catchment disturbance and stream metabolism: Patterns in ecosystem respiration and gross primary production along a gradient of upland soil and vegetation disturbance. Journal of the North American Benthological Society, 24: 538-552.

Hutmacher, A. M., G. N. Zaines, J. Martin \& D. M. Green, 2013. Vegetation structure along urban ephemeral streams in southeastern Arizona. Urban Ecosystems, 17: 349-368.

Irwin, E. G. \& N. E. Bockstael, 2007. The evolution of urban sprawl: Evidence of spatial heterogeneity and increasing land fragmentation. Proceedings of the National Academy of Sciences of the USA, 104: 20672-20677.

Johnson, S. L. \& J. A. Jones, 2000. Stream temperature responses to forest harvest and debris flows in western Cascades, Oregon. Canadian Journal of Fisheries and Aquatic Sciences, 57: 30-39.

Kaufman, L. \& P. J. Rousseeuw, 1990. Finding Groups in Data: An Introduction to Cluster Analysis. John Wiley \& Sons, New York, New York.

Kolb, A. \& M. Diekmann, 2005. Effects of life-history traits on responses of plant species to forest fragmentation. Conservation Biology, 19: 929-938.

Konrad, C. P. \& D. B. Booth, 2005. Hydrologic changes in urban streams and their ecological significance. American Fisheries Society Symposium, 47: 157-177.

Lin, L., M. Cao, Y. He, J. Baskin \& C. Baskin, 2006. Nonconstituent species in soil seed banks as indicators of anthropogenic disturbance in forest fragments. Canadian Journal of Forest Research, 36: 2300-2316.

Loewenstein, N. \& E. F. Loewenstein, 2005. Non-native plants in the understory of riparian forests across a land use gradient in the Southeast. Urban Ecosystems, 8: 79-91. 
Lorenz, A. W. \& C. K. Feld, 2013. Upstream river morphology and riparian land use overrule local restoration effects on ecological status assessment. Hydrobiologia, 704: 489-501.

Magee, T. K, P. L. Ringold \& M. A. Bollman, 2008. Alien species importance in native vegetation along wadeable streams, John Day River basin, Oregon, USA. Plant Ecology, 195: 287-307.

McEuen, A. B. \& L. M. Curran, 2004. Seed dispersal and recruitment limitation across spatial scales in temperate forest fragments. Ecology, 85: 507-518.

McKinney, M. L., 2008. Effects of urbanization on species richness: A review of plants and animals. Urban Ecosystems, 11: 161-176.

Meek, C. S., D. M. Richardson \& L. Mucina, 2010. A river runs through it: Land-use and the composition of vegetation along a riparian corridor in the Cape Floristic Region, South Africa. Biological Conservation, 143: 156-164.

Metro, 2013. Welcome to Metro. Online [URL] http://www. oregonmetro.gov (Accessed on 19 August 2013).

Metro Data Resource Center, 2007. RLIS Discovery. Online [URL] http://rlisdiscovery.oregonmetro.gov (Accessed on 19 August 2013).

Moffatt, S. F. \& S. M. McLachlan, 2004. Understorey indicators of disturbance for riparian forests along an urban-rural gradient in Manitoba. Ecological Indicators, 4: 1-16.

Moffatt, S. F., S. M. McLachlan \& N. C. Kenkel, 2004. Impacts of land use on riparian forest along an urban-rural gradient in southern Manitoba. Plant Ecology, 174: 119-135.

Naiman, R. \& H. Decamps, 1997. The ecology of interfaces: Riparian zones. Annual Review of Ecology and Systematics, 28: 621-658.

Nakano, S. \& M. Murakami, 2001. Reciprocal subsidies: Dynamic interdependence between terrestrial and aquatic food webs. Proceedings of the National Academy of Sciences of the USA, 98: 166-170.

Newham, M. J., C. S. Fellows \& F. Sheldon, 2011. Functions of riparian forest in urban catchments: A case study from subtropical Brisbane, Australia. Urban Ecosystems, 14: 165-180.

Nucci, A., C. Angiolini, M. Landi \& G. Bacchetta, 2012. Regional and local patterns of riparian flora: Comparison between insular and continental Mediterranean rivers. Écoscience, 19: $213-224$.

Oksanen, J., F. G. Blanchet, R. Kindt, P. Legendre, P. R. Minchin, R. B. O'Hara, G. L. Simpson, P. Solymos, M. H. H. Stevens \& H. Wagner, 2012. vegan: Community Ecology Package. R Package Version 2.0-5. Online [URL] http://cran.r-project. org/package $=$ vegan (Accessed on 19 August 2013)

Oneal, A. S. \& J. T. Rotenberry, 2008. Riparian plant composition in an urbanizing landscape in southern California, USA. Landscape Ecology, 23: 553-567.

Ozawa, C. P. \& J. A. Yeakley, 2007. Performance of management strategies in the protection of riparian vegetation in three Oregon cities. Journal of Environmental Planning and Management, 50: 803-822.

Pearson, R. G. \& T. P. Dawson, 2005. Long-distance plant dispersal and habitat fragmentation: Identifying conservation targets for spatial landscape planning under climate change. Biological Conservation, 123: 389-401.

Pennington, D. N., J. R. Hansel \& D. L. Gorchov, 2010. Urbanization and riparian forest woody communities: Diversity, composition, and structure within a metropolitan landscape. Biological Conservation, 143: 182-194.
Pojar, J. \& A. MacKinnon, 1994. Plants of the Pacific Northwest Coast. Revised Edition. Lone Pine Publishing, Vancouver, British Columbia.

Porter, E. E., B. R. Forschner \& R. B. Blair, 2001. Woody vegetation and canopy fragmentation along a forest-to-urban gradient. Urban Ecosystems, 5: 131-151.

Puşcaş, M. \& P. Choler, 2012. A biogeographic delineation of the European alpine system based on a cluster analysis of Carex curvula-dominated grasslands. Flora, 207: 168-178.

R Development Core Team, 2012. R: A Language and Environment for Statistical Computing. R Foundation for Statistical Computing, Vienna.

Richardson, J. S., R. J. Naiman \& P. A. Bisson, 2012. How did fixed-width buffers become standard practice for protecting freshwaters and their riparian areas from forest harvest practices? Freshwater Science, 31: 232-238.

Rockey, C., 2012. Portland climate normal (1981-2010), means and extremes. National Oceanic and Atmospheric Administration National Weather Service Forecast Office, Portland, Oregon. Online [URL] http://www.wrh.noaa.gov/pqr/ pdxclimate/pg121.pdf (Accessed on 27 January 2014).

Salinas, M. J. \& J. J. Casas, 2007. Riparian vegetation of two semi-arid Mediterranean rivers: Basin-scale responses of woody and herbaceous plants to environmental gradients. Wetlands, 27: 831-845.

Sarr, D. A. \& D. E. Hibbs, 2007. Woody riparian plant distributions in western Oregon, USA: Comparing landscape and local scale factors. Plant Ecology, 190: 291-311.

Strohbach, M., V. Audorff \& C. Beierkuhnlein, 2009. Drivers of plant species composition in siliceous spring ecosystems: Groundwater chemistry, catchment traits, or spatial factors? Journal of Limnology, 68: 375-384.

Sweeney, B. W., T. L. Bott, L. A. Kaplan, J. D. Newbold, L. J. Standley, W. C. Hession, R. J. Horwitz \& M. G. Wolman, 2004. Riparian deforestation, stream narrowing, and loss of stream ecosystem services. Proceedings of the National Academy of Sciences of the USA, 101: 14132-14137.

Tabacchi, E. \& A. Planty-Tabacchi, 2005. Exotic and native plant community distributions within complex riparian landscapes: A positive correlation. Écoscience, 12: 412-423.

Tabacchi, E., L. Lambs, H. Guilloy, A. Planty-Tabacchi, E. Muller \& H. Decamps, 2000. Impacts of riparian vegetation on hydrological processes. Hydrological Processes, 14: 2959-2976.

Therneau, T., B. Atkinson \& B. Ripley, 2012. rparg: Recursive Partitioning. R Package Version 3.1-55. Online [URL] http://cran.r-project.org/package=rpart (Accessed on 19 August 2013).

USDA NRCS, 2013. The PLANTS Database. National Plant Data Team, Greensboro, North Carolina. Online [URL] http://plants. usda.gov (Accessed on 19 August 2013).

USGS Watershed Boundary Dataset for HUC 2-17. Online [URL] http://nhd.usgs.gov (Accessed on 19 August 2013).

Vidra, R. L., T. H. Shear \& T. R. Wentworth, 2006. Testing the paradigms of exotic species invasion in urban riparian forests. Natural Areas Journal, 26: 339-350.

Walsh, C. J., A. H. Roy, J. W. Feminella, P. D. Cottingham, P. M. Groffman \& P. M. Raymond II, 2005. The urban stream syndrome: Current knowledge and the search for a cure. Journal of the North American Benthological Society, 24: 706-723.

Wania, A., I. Kuhn \& S. Klotz, 2006. Plant richness patterns in agricultural and urban landscapes in Central Germany: Spatial gradients of species richness. Landscape and Urban Planning, 75: $97-110$ 